\title{
An analysis of the response of sugar beet and potatoes to fertilizer nitrogen and soil mineral nitrogen
}

\author{
J. J. NEETESON \& H. J. C. ZWETSLOOT \\ Institute for Soil Fertility, P.O. Box 30003, NL 9750 RA Haren, Netherlands
}

Received 8 February 1989; accepted 1 March 1989

\begin{abstract}
A statistical analysis was performed to investigate if, and to what extent, the response of sugar beet and potatoes to fertilizer nitrogen depended on the amount of mineral nitrogen already present in the soil, soil type, and prior application of organic manures. For this purpose the results of 150 field trials with sugar beet and 98 with potatoes were used. The analysis was focussed on the within-block stratum of variation in yield, where regression models were fitted to describe the response to nitrogen. For both sugar beet and potatoes the best fit was obtained when not only fertilizer nitrogen was taken into account, but also soil mineral nitrogen, soil type, and prior application of organic manures. The response to fertilizer nitrogen was weaker as the amount of soil mineral nitrogen was larger. The optimum amount of fertilizer nitrogen plus soil mineral nitrogen required was larger on sandy soils than on loam and clay soils. The difference was about $20 \mathrm{~kg} \mathrm{~N}$ per ha for sugar beet and $100 \mathrm{~kg} \mathrm{~N}$ per ha for potatoes. When organic manures were applied prior to the aplication of fertilizer nitrogen, the optimum for both sugar beet and potatoes was $15-50 \mathrm{~kg} \mathrm{~N}$ per ha lower than without application of organic manures.
\end{abstract}

Keywords: fertilizer nitrogen, nitrogen fertilizer recommendation, nitrogen response curve, potatoes, soil mineral nitrogen, sugar beet

\section{Introduction}

In the Netherlands, nitrogen fertilizer recommendations for arable crops are based on numerous field trials (Ris et al., 1981). On each experimental site, soil mineral nitrogen was measured in early spring and increasing amounts of fertilizer nitrogen were applied to determine the optimum application rate from the response curve. The recommendations for sugar beet and potatoes are derived from the linear relationship between the amount of mineral nitrogen (ammonium $\mathrm{N}+$ nitrate $\mathrm{N}$ ) present in the soil in early spring and the economically optimum application rate of fertilizer nitrogen (Anon., 1986). The larger the amount of soil mineral nitrogen, the lower the recommended application rate of fertilizer nitrogen.

Many trials were conducted because it was believed that the linear relationship between soil mineral nitrogen and the optimum application rate of fertilizer nitro- 
gen could be reliably established only on the basis of a large number of data points. The relationship was indeed found to be significant, but the variation around the regression line was considerable, e.g. $r^{2}=0.30$ with 148 sugar-beet trials and $r^{2}=$ 0.25 with 83 potato trials (Neeteson, 1982). The wide variation prevented a clear differentiation between soil types and/or fields with or without prior application of organic manures.

Neeteson \& Wadman (1987) have shown that the economically optimum application rate of fertilizer nitrogen for sugar beet and potatoes, derived from response curves of individual trials, generally has a large error. It is likely that the considerable variation around regression lines of the relationship between soil mineral nitrogen and the optimum application rate of fertilizer nitrogen is partly due to the large error in the determination of the optima.

To develop a basis for refinement of the current recommendations, a statistical analysis was performed to investigate whether the response of sugar beet and potatoes was not only dependent on the amount of mineral nitrogen already present in the soil, but also on soil type and prior application of organic manures. For this purpose the results of 150 field trials with sugar beet and 98 with potatoes were used. The analysis was focussed on the within-block stratum of variation in yield, where regression models were fitted to describe the response to nitrogen.

\section{Materials and methods}

\section{Experimental design}

In cooperation with the Sugar Beet Research Institute (IRS, Bergen op Zoom) and the Research Station for Arable Farming and Field Production of Vegetables (PAGV, Lelystad), 150 field trials with sugar beet (Beta vulgaris L. cv. Monohil) and 98 field trials with potatoes (Solanum tuberosum L. cv. Bintje) were conducted in the period 1973-1982. There were altogether 167 sugar beet and 99 potato trials (Neeteson \& Wadman, 1987), but trials with incomplete data on soil mineral nitrogen were omitted. Moreover, some sugar-beet trials were excluded because of unrealistically high levels of soil mineral nitrogen in early spring $(>300 \mathrm{~kg} \mathrm{~N}$ per ha in the $0-100 \mathrm{~cm}$ layer). The trials were laid out in all parts of the Netherlands. The distribution of the trials over years and soil types is given in Table 1 . The soils were classified on the basis of the particle-size distribution in the plough layer (Steur \& Heijink, 1987). In 63 of the sugar beet and 50 of the potato trials, organic manures were applied in autumn or early winter preceding sugar beet or potato culture. The organic manures were green manures (mostly Italian ryegrass (Lolium multiflorum Lamk.) or vetch (Vicia sativa L.) and/or slurries (cattle, pig or poultry slurry; about $50 \mathrm{t} \mathrm{ha}^{-1}$ ). Table 2 shows the distribution over soil types of the trials with application of organic manures.

In the sugar-beet trials, soil mineral nitrogen content was measured in early spring in samples from the layers $0-30,30-60$, and $60-100 \mathrm{~cm}$, whereas in the potato trials the layers $0-30$ and $30-60 \mathrm{~cm}$ were sampled. For each soil sample approximately 12 cores were mixed. Nitrate and ammonium were extracted with $1 \mathrm{M} \mathrm{NaCl}$ 
Table 1. Distribution of the trials over years and soil types.

\begin{tabular}{|c|c|c|c|c|c|c|c|c|}
\hline \multirow[t]{2}{*}{ Year } & \multicolumn{4}{|c|}{ Sugar beet } & \multicolumn{4}{|c|}{ Potatoes } \\
\hline & sand & loam & clay & total & sand & loam & clay & total \\
\hline 1973 & 0 & 0 & 0 & 0 & 1 & 3 & 1 & 5 \\
\hline 1974 & 1 & 6 & 0 & 7 & 1 & 3 & 0 & 4 \\
\hline 1975 & 3 & 3 & 2 & 8 & 1 & 3 & 0 & 4 \\
\hline 1976 & 3 & 5 & 2 & 10 & 2 & 4 & 1 & 7 \\
\hline 1977 & 12 & 20 & 10 & 42 & 1 & 4 & 1 & 6 \\
\hline 1978 & 9 & 16 & 15 & 40 & 1 & 5 & 1 & 7 \\
\hline 1979 & 8 & 22 & 13 & 43 & 1 & 4 & 1 & 6 \\
\hline 1980 & 0 & 0 & 0 & 0 & 5 & 13 & 7 & 25 \\
\hline 1981 & 0 & 0 & 0 & 0 & 8 & 11 & 6 & 25 \\
\hline 1982 & 0 & 0 & 0 & 0 & 4 & 5 & 0 & 9 \\
\hline Total & 36 & 72 & 42 & 150 & 25 & 55 & 18 & 98 \\
\hline
\end{tabular}

Table 2. Distribution over soil types of the trials with application of organic manures.

\begin{tabular}{|c|c|c|c|c|c|c|c|c|}
\hline \multirow{2}{*}{$\begin{array}{l}\text { Type(s) of } \\
\text { organic manure }\end{array}$} & \multicolumn{4}{|c|}{ Sugar beet } & \multicolumn{4}{|c|}{ Potatoes } \\
\hline & sand & loam & clay & total & sand & loam & clay & tota \\
\hline Green manures & 2 & 26 & 18 & 46 & 2 & 15 & 7 & 24 \\
\hline Slurries & 10 & 2 & 1 & 13 & 8 & 7 & 1 & 16 \\
\hline Green manures + slurries & 2 & 1 & 1 & 4 & 1 & 5 & 4 & 10 \\
\hline Total & 14 & 29 & 20 & 63 & 11 & 27 & 12 & 50 \\
\hline
\end{tabular}

and determined colorimetrically with a Technicon Autoanalyser (Ris et al., 1981). For conversion of the measured soil mineral nitrogen contents from mg per $\mathrm{kg}$ soil to $\mathrm{kg} \mathrm{ha}^{-1}$, the bulk density of each soil layer was measured in each experimental field in four replications. Six rates of fertilizer nitrogen ranging from 0 to 200 or 250 $\mathrm{kg} \mathrm{ha}^{-1}$ were applied in four replications in the sugar-beet trials. In the potato trials, seven rates ranging from 0 to $400 \mathrm{~kg} \mathrm{ha}^{-1}$ were applied in three replications. At harvest, fresh yield and sugar content of the beets were determined for each sugar-beet plot, and fresh tuber yield was determined for each potato plot. The nitrogen contents of the potato tubers were determined in the fresh material according to the Kjeldahl-method.

\section{Statistical analysis}

When results of field trials performed in different years and at different sites are analysed together, several strata of variation have to be dealt with. Usually the variation between experiments is large and the within-experiment variation differs between experiments. The following statistical model was used to describe the strata 


\section{J. J. NEETESON AND H. J. C. ZWETSLOOT}

of variation and the yield response to nitrogen:

$$
\underline{\mathrm{Y}}_{\mathrm{klm}}=\mu+\underline{\mathrm{T}}_{\mathrm{k}}+\underline{\mathrm{B}}_{\mathrm{kl}}+\mathrm{f}(\mathrm{N})+\underline{\mathrm{e}}_{\mathrm{klm}}
$$

where $\underline{\mathrm{Y}}_{\mathrm{klm}}$ is the yield of a plot and $\mu$ is the overall mean yield in $\mathrm{t} \mathrm{ha}^{-1}$. Subscripts $\mathrm{k}$, 1 , and $\mathrm{m}$ refer to trial $(\mathrm{k}=1$. . ., 150 (for sugar beet) or 98 (for potatoes)), block $(1=1, \ldots, 4$ (for sugar beet) or 3 (for potatoes)), and plot $(\mathrm{m}=1, \ldots, 6$ (for sugar beet) or 7 (for potatoes)), respectively. $\underline{T}_{k}$ describes the stratum of variation between trials $\left(\Sigma \underline{T}_{k}=0\right)$, and $\underline{B}_{k l}$ the variation due to blocks within trials $\left(\Sigma \underline{B}_{k l}=\right.$ $0)$. The variation within the blocks is described by $f(N)$, the function which describes yield response to nitrogen; the term $\mathrm{e}_{\mathrm{klm}}$ represents the vector of residuals. This vector is normally distributed $\left(\underline{e}_{\mathrm{klm}}=\mathbf{N}\left(0, \sigma^{2}\right)\right)$. No attempt was made to account for the wide variation between experiments, which is due to differences in weather conditions, soils, and crop management practices. The vectors $\underline{T}_{k}$ and $\underline{B}_{k l}$ were estimated from the data before further analysis was performed. The analysis was focussed on the within-block stratum of variation, where regression models were fitted. To correct for the non-homogeneity of variances, the regression was weighted with the inverse of the square root of the residual variance within each individual experiment.

For sugar beet, yield response to nitrogen was described by a modified exponential curve (Neeteson \& Wadman, 1987):

$$
\mathrm{f}(\mathrm{N})=\beta_{0}+\beta_{1} \mathrm{e}^{\alpha \mathrm{N}}+\beta_{2} \mathrm{~N} ; \quad \beta_{0}>0 ; \beta_{1}, \beta_{2}, \text { and } \alpha<0
$$

where $\mathrm{f}(\mathrm{N})$ describes fresh beet yield with a sugar content of $16 \%(\mathrm{tha})$ and $\mathrm{N}$ is the amount of nitrogen $\left(\mathrm{kg} \mathrm{ha}^{-1}\right) . \beta_{0}, \beta_{1}, \beta_{2}$, and $\alpha$ are coefficients which are estimated by non-linear regression analysis. The linear term $\beta_{2} \mathrm{~N}$ is included in the equation to allow for decreasing yields at nitrogen rates beyond the rate for maximum yield.

For potato, $\beta_{2}$ was never found to be significant. Therefore, response of potato to nitrogen is described by a common exponential curve:

$$
\mathrm{f}(\mathrm{N})=\beta_{0}+\beta_{1} \mathrm{e}^{a \mathrm{~N}} \quad \beta_{0}>0 ; \beta_{1} \text { and } \alpha<0
$$

where $\mathrm{f}(\mathrm{N})$ describes fresh tuber yield $\left(\mathrm{tha}^{-1}\right)$, and $\beta_{0}, \beta_{1}, \alpha$ and $\mathrm{N}$ have the same meaning as in Equation 2.

The economical optimum $\left(\mathrm{N}_{\mathrm{op}}\right)$ of the response curves is calculated by:

$$
\begin{aligned}
& \mathrm{N}_{\mathrm{op}}=\ln \left\{\left(\mathrm{P}-\mathrm{b}_{2}\right) / \mathrm{ab}_{1}\right\} / \mathrm{a} \\
& \mathrm{N}_{\mathrm{op}}=\ln \left\{\mathrm{P} / \mathrm{ab}_{1}\right\} / \mathrm{a}
\end{aligned}
$$

for sugar beet and potatoes, respectively, where $\mathrm{P}$ equals ratio of cost of $1 \mathrm{~kg}$ nitrogen to the price of 1 tonne crop yield, and $b_{1}, b_{2}$ and a are estimated values of $\beta_{1}, \beta_{2}$, and $\alpha$. The $90 \%$ confidence intervals for the optima were calculated as described by Neeteson and Wadman (1987), but now also account was taken of the variance of the coefficient $a$. 
A kind of forward selection was used to find the best-fitting model for the description of the response of sugar beet and potato to nitrogen. Firstly, the simplest model was fitted. Then, parameters were added so that the models became more complex. Sequential models were compared by means of $F$-tests; the variance in the denominator of the $F$-statistics was taken from the most complex model. As a result of the very large number of degrees of freedom, significant $F$-tests could be obtained with extremely complex models. However, models were not allowed to become too complex. Model selection was terminated before models were obtained which would not be applicable in practical situations.

The statistical analyses were performed with Genstat 5, Release 1.0 (Lawes Agricultural Trust, Rothamsted Experimental Station).

\section{Results}

\section{Sugar beet}

Yield response to nitrogen was fitted to various models which were based on Equation 2 (Table 3). In Model 1, yield only depends on the amount of fertilizer nitrogen applied, whereas in Models 2, 3, and 4 also soil mineral nitrogen in the various layers is accounted for. Inclusion of soil mineral nitrogen, especially the amounts in the layers $0-30$ and $30-60 \mathrm{~cm}$, considerably improved the goodness of fit of response to nitrogen (comparison of Model 2 with Model 1: $F=303.2, P<0.001$; comparison of Model 3 with Model 2: $F=106.8, P<0.001)$. Inclusion of soil mineral nitrogen in the $60-100 \mathrm{~cm}$ layer further improved the goodness of fit significantly (comparison of Model 4 with Model 3: $F=5.8, P<0.001$ ). It should be noted here that, due to the large number of observations, even very small effects will tend to be significant. The magnitude of the effect and its practical implication are therefore far more important than its significance. The estimated values of coefficients $\alpha_{1}, \alpha_{2}, \alpha_{3}$, and $\alpha_{4}$ in Model 4 of Table 3 are $-0.0143,-0.0115,-0.0122$, and $-0.0022 \mathrm{ha} \mathrm{kg}^{-1}$, respectively. Apparently, the contribution of soil mineral nitrogen in the $60-100 \mathrm{~cm}$ layer (estimation of $\alpha_{4}$ ) was only 15-19\% of that of fertilizer nitrogen or soil mineral nitrogen in the 0-30 and 30-60 cm layer (estimations of $\alpha_{1}, \alpha_{2}$, and $\alpha_{3}$ ). To simplify the model, the minor contribution of soil mineral nitrogen in the $60-100 \mathrm{~cm}$ layer was neglected (Model 3). Still, Model 3 remains complicated and cannot be easily interpreted. To simplify the model further, the weighted contributions of fertilizer nitrogen and soil mineral nitrogen were calculated on the basis of the estimated values of $\alpha_{1}\left(-0.0147 \mathrm{ha} \mathrm{kg}^{-1}\right), \alpha_{2}\left(-0.0120 \mathrm{ha} \mathrm{kg}^{-1}\right)$, and $\alpha_{3}\left(-0.0147 \mathrm{ha} \mathrm{kg}^{-1}\right)$ in Model 3:

$$
\mathrm{N}_{\mathrm{t}}=\mathrm{N}_{\mathrm{f}}+0.82 \mathrm{~N}_{\mathrm{m} 30}+1.00 \mathrm{~N}_{\mathrm{m} 60}
$$

where $\mathrm{N}_{\mathrm{f}}$ is the amount of fertilizer nitrogen applied in $\mathrm{kg} \mathrm{ha}^{-1}$, and $\mathrm{N}_{\mathrm{m} 30}$ and $\mathrm{N}_{\mathrm{m} 60}$ are the amounts of soil mineral nitrogen in the $0-30$ and $30-60 \mathrm{~cm}$ layer in $\mathrm{kg} \mathrm{ha}^{-1}$, respectively. The estimated values of $\beta_{2}$ were not weighted in Equation 6 , because the linear part of the model has a far less pronounced effect on the optimum than 
Table 3. Analysis of variance of yields in the 150 sugar beet trials.

\begin{tabular}{|c|c|c|}
\hline Source of variation & $\begin{array}{l}\text { Sum of } \\
\text { squares }\end{array}$ & $\begin{array}{l}\text { Degrees of } \\
\text { freedom }\end{array}$ \\
\hline Total & 156470 & 3599 \\
\hline Trial stratum & 117347 & 149 \\
\hline Trial $\times$ block stratum & 3186 & 450 \\
\hline Trial $\times$ block $\times$ units stratum & 35937 & 3000 \\
\hline Model 1: $\mathrm{f}(\mathrm{N})=\beta_{0}+\beta_{1} \mathrm{e}^{\alpha \mathrm{Nf}_{\mathrm{f}}}+\beta_{2} \mathrm{~N}_{\mathrm{f}}$ & 12115 & 3 \\
\hline Model 2: $\mathrm{f}(\mathrm{N})=\beta_{0}+\beta_{1} \mathrm{e}^{\left(\alpha_{1} \mathrm{~N}_{\mathrm{f}}+\alpha_{2} \mathrm{~N}_{\mathrm{m} 30)}\right.}+\beta_{21} \mathrm{~N}_{\mathrm{f}}+\beta_{22} \mathrm{~N}_{\mathrm{m} 30}$ & 15856 & 5 \\
\hline $\begin{aligned} \text { Model 3: } \mathrm{f}(\mathrm{N})= & \beta_{0}+\beta_{1} \mathrm{e}^{\left(\alpha_{1} \mathrm{~N}_{\mathrm{f}}+\alpha_{2} \mathrm{~N}_{\mathrm{m} 30}+\alpha_{3} \mathrm{~N}_{\mathrm{m} 60)}\right)}+ \\
& \beta_{21} \mathrm{~N}_{\mathrm{f}}+\beta_{22} \mathrm{~N}_{\mathrm{m} 30}+\beta_{23} \mathrm{~N}_{\mathrm{m} 60}\end{aligned}$ & 17173 & 7 \\
\hline $\begin{aligned} \text { Model 4: } \mathrm{f}(\mathrm{N})= & \beta_{0}+\beta_{1} \mathrm{e}^{\left(\alpha_{1} \mathrm{~N}_{\mathrm{f}}+\alpha_{2} \mathrm{~N}_{\mathrm{m} 30}+\alpha_{3} \mathrm{~N}_{\mathrm{m} 60}+\alpha_{4} \mathrm{~N}_{\mathrm{m} 100)}\right.}+ \\
& \beta_{21} \mathrm{~N}_{\mathrm{f}}+\beta_{22} \mathrm{~N}_{\mathrm{m} 30}+\beta_{23} \mathrm{~N}_{\mathrm{m} 60}+\beta_{24} \mathrm{~N}_{\mathrm{m} 100}\end{aligned}$ & 17245 & 9 \\
\hline Model 5: $\mathrm{f}(\mathrm{N})=\beta_{0}+\beta_{1} \mathrm{e}^{\alpha N_{\mathrm{t}}}+\beta_{2} \mathrm{~N}_{\mathrm{t}}$ & 16513 & 3 \\
\hline Model 6: $\mathrm{f}(\mathrm{N})=\beta_{0 \mathrm{j}}+\beta_{1 \mathrm{j}} \mathrm{e}^{\alpha_{\mathrm{j}} \mathrm{N}_{\mathrm{t}}}+\beta_{2 \mathrm{j}} \mathrm{N}_{\mathrm{t}}$ & 17223 & 7 \\
\hline Model 7: $\mathrm{f}(\mathrm{N})=\beta_{0 \mathrm{ij}}+\beta_{1 \mathrm{ij}} \mathrm{e}^{\alpha_{\mathrm{ij}} \mathrm{N}_{\mathrm{t}}}+\beta_{2 \mathrm{ij}} \mathrm{N}_{\mathrm{t}}$ & 17579 & 23 \\
\hline Residual of Model 7 & 18358 & 2977 \\
\hline
\end{tabular}

See Equation 2 for meaning of $\mathrm{f}(\mathrm{N}), \beta_{0}, \beta_{1}, \beta_{2}$ and $\alpha ; \mathrm{N}_{\mathrm{f}}=$ fertilizer- $\mathrm{N}$ rate in $\mathrm{kg} \mathrm{ha}^{-1} ; \mathrm{N}_{\mathrm{m} 30}=$ soil mineral $\mathrm{N}$ in the layer $0-30 \mathrm{~cm}$ in kg ha ${ }^{-1} ; \mathrm{N}_{\mathrm{m} 60}=$ soil mineral $\mathrm{N}$ in the layer $30-60 \mathrm{~cm}$ in kg ha ${ }^{-1} ; \mathrm{N}_{\mathrm{m} 100}=$ soil mineral $\mathrm{N}$ in the layer $60-100 \mathrm{~cm}$ in kg ha-1; $\mathrm{N}_{\mathrm{t}}=\mathrm{N}_{\mathrm{f}}+0.82 \mathrm{~N}_{\mathrm{m} 30}+1.00 \mathrm{~N}_{\mathrm{m} 60} ; \mathrm{i}=$ index for soil type; $\mathrm{j}=$ index for application of organic manures.

the exponential part. In Models 5, 6 and 7 the amount of available nitrogen was assumed to equal $\mathrm{N}_{\mathrm{t}}$. Somewhat less of the variance in yield was accounted for in Model 5 than in Model 3, but the number of degrees of freedom in Model 5 was also less than half of that in Model 3. Compared with Model 5, a significantly better fit of the nitrogen response was obtained in Model 6, in which a distinction is made between fields which did and did not receive organic manures prior to the application of inorganic fertilizer nitrogen (comparison of Model 6 with Model 5: $F=28.8, P<$ 0.001 ). The best fit, however, was obtained in Model 7, in which not only the application of organic manures is taken into account, but also the soil type (comparison of Model 7 with Model 6: $F=3.6, P<0.001$ ).

The estimated values of the regression coefficients of Model 7 are given in Table 4. The economically optimum nitrogen requirement for the various soil types with and without application of organic manures was then calculated (Table 5). The ratio of the cost of $1 \mathrm{~kg}$ nitrogen (fertilizer + soil mineral nitrogen according to Equation 6) to the price of 1 tonne sugar beet, $\mathrm{P}$ in Equation 4 was assumed to be 0.008 . Without organic manures the optimum nitrogen requirement (fertilizer + soil mineral nitrogen) on sandy soils was about $20 \mathrm{~kg} \mathrm{~N}$ per ha higher than that on loam and clay soils. When organic manures were applied prior to the application of fertilizer 
Table 4. Response curves of sugar beet. Estimated values of the regression coefficients of Model 7 in Table 3. Standard errors are given in parentheses.

\begin{tabular}{|c|c|c|c|c|c|}
\hline $\begin{array}{l}\text { Soil } \\
\text { type }\end{array}$ & $\begin{array}{l}\text { Organic } \\
\text { manures }\end{array}$ & $\begin{array}{l}\mathrm{b}_{0} \\
\left(\mathrm{tha} \mathrm{a}^{-1}\right)\end{array}$ & $\begin{array}{l}b_{1} \\
\left(t_{h a^{-1}}\right)\end{array}$ & $\begin{array}{l}\mathrm{b}_{2} \\
\left(\mathrm{t} \mathrm{kg}^{-1}\right)\end{array}$ & $\begin{array}{l}\text { a } \\
\left(\mathrm{ha} \mathrm{kg}^{-1}\right)\end{array}$ \\
\hline Sand & $\begin{array}{l}\text { no } \\
\text { yes }\end{array}$ & $\begin{array}{ll}70.8 & (4.35) \\
67.8 & (2.55)\end{array}$ & $\begin{array}{ll}-32.7 & (3.34) \\
-26.6 & (4.49)\end{array}$ & $\begin{array}{l}-0.022(0.013) \\
-0.024(0.008)\end{array}$ & $\begin{array}{l}-0.0129(0.003) \\
-0.0178(0.006)\end{array}$ \\
\hline Loam & $\begin{array}{l}\text { no } \\
\text { yes }\end{array}$ & $\begin{array}{l}94.3(10.69) \\
82.8 \quad(8.61)\end{array}$ & $\begin{array}{lr}-53.9 & (10.03) \\
-36.6 & (7.61)\end{array}$ & $\begin{array}{l}-0.095(0.027) \\
-0.066(0.022)\end{array}$ & $\begin{array}{l}-0.0083(0.002) \\
-0.0091(0.003)\end{array}$ \\
\hline Clay & $\begin{array}{l}\text { no } \\
\text { yes }\end{array}$ & $\begin{array}{ll}78.7 & (4.39) \\
69.6 & (2.45)\end{array}$ & $\begin{array}{ll}-40.6 & (3.68) \\
-32.3 & (2.92)\end{array}$ & $\begin{array}{l}-0.051(0.012) \\
-0.031(0.009)\end{array}$ & $\begin{array}{l}-0.0115(0.002) \\
-0.0196(0.004)\end{array}$ \\
\hline
\end{tabular}

Table 5. Economically optimum nitrogen requirement (fertilizer + soil mineral nitrogen according to Equation 6 of sugar beet as affected by soil type and application of organic manures. The $90 \%$ confidence interval for the optima is given in parentheses.

\begin{tabular}{lll}
\hline Soil type & $\begin{array}{l}\text { Organic } \\
\text { manures }\end{array}$ & $\begin{array}{l}\text { Optimum nitrogen requirement } \\
\left(\mathrm{kg} \mathrm{ha}^{-1}\right)\end{array}$ \\
Sand & no & $205(192-235)$ \\
& yes & $153(136-172)$ \\
Loam & no & $176(170-183)$ \\
& yes & $165(155-171)$ \\
Clay & no & $180(172-193)$ \\
& yes & $142(134-158)$ \\
\hline
\end{tabular}

nitrogen, the optimum was $15-50 \mathrm{~kg} \mathrm{~N}$ per ha lower than without application of organic manures.

\section{Potatoes}

Yield response to nitrogen was fitted to various models which were based on Equation 3 (Table 6). In Model 1, yield was fitted as being dependent only on the amount of fertilizer nitrogen applied, whereas in Models 2 and 3 also soil mineral nitrogen in the various layers was taken into account. Inclusion of soil mineral nitrogen, especially the amount in the layer $0-30 \mathrm{~cm}$, significantly improved the fit of response to nitrogen (comparison of Model 2 with Model 1: $F=152.5, P<0.001$; comparison of Model 3 to Model 2: $F=19.8, P<0.001$ ). The estimated values of coefficients $\alpha_{1}, \alpha_{2}$, and $\alpha_{3}$ are $-0.012,-0.008$, and $-0.004 \mathrm{ha} \mathrm{kg}^{-1}$, respectively. The total contribution of soil mineral nitrogen and fertilizer nitrogen to the nitrogen response, $\mathrm{N}_{\mathrm{t}}$, can thus be described as:

$$
\mathrm{N}_{\mathrm{t}}=\mathrm{N}_{\mathrm{f}}+0.67 \mathrm{~N}_{\mathrm{m} 30}+0.33 \mathrm{~N}_{\mathrm{m} 60}
$$

where $\mathrm{N}_{\mathrm{f}}, \mathrm{N}_{\mathrm{m} 30}$, and $\mathrm{N}_{\mathrm{m} 60}$ have the same meaning as in Equation 6. Apparently, the 
Table 6. Analysis of variance of yields in the 98 potato trials.

\begin{tabular}{lcc}
\hline Source of variation & $\begin{array}{l}\text { Sum of } \\
\text { squares }\end{array}$ & $\begin{array}{l}\text { Degrees of } \\
\text { freedom }\end{array}$ \\
Total & 82149 & 2057 \\
Trial stratum & 58878 & 97 \\
Trial $\times$ block stratum & 1459 & 196 \\
Trial $\times$ block $\times$ units stratum & 21812 & 1764 \\
$\quad$ Model 1: $\mathrm{f}(\mathrm{N})=\beta_{0}+\beta_{1} \mathrm{e}^{\alpha \mathrm{N}_{\mathrm{f}}}$ & 11878 & 2 \\
Model 2: $\mathrm{f}(\mathrm{N})=\beta_{0}+\beta_{1} \mathrm{e}^{\left(\alpha_{1} \mathrm{~N}_{\mathrm{f}}+\alpha_{2} \mathrm{~N}_{\mathrm{m} 30)}\right.}$ & 12640 & 3 \\
Model 3: $\mathrm{f}(\mathrm{N})=\beta_{0}+\beta_{1} \mathrm{e}^{\left(\alpha_{1} \mathrm{~N}_{\mathrm{f}}+\alpha_{2} \mathrm{~N}_{\mathrm{m} 30}+\alpha_{3} \mathrm{~N}_{\mathrm{m} 60)}\right.}$ & 12739 & 4 \\
Model 4: $\mathrm{f}(\mathrm{N})=\beta_{0}+\beta_{1} \mathrm{e}^{\alpha \mathrm{N}_{\mathrm{t}}}$ & 12739 & 2 \\
Model 5: $\mathrm{f}(\mathrm{N})=\beta_{0 \mathrm{j}}+\beta_{1 \mathrm{j}} \mathrm{e}^{\mathrm{a}_{\mathrm{j}} \mathrm{N}_{\mathrm{t}}}$ & 12897 & 5 \\
Model 6: $\mathrm{f}(\mathrm{N})=\beta_{0 \mathrm{ij}}+\beta_{1 \mathrm{ij}} \mathrm{e}^{\alpha_{\mathrm{j}} \mathrm{N}_{\mathrm{t}}}$ & 13082 & 17 \\
Residual of Model 6 & 8730 & 1747 \\
\hline
\end{tabular}

See Equation 3 for meaning of $\mathrm{f}(\mathrm{N}), \beta_{0}, \beta_{1}$, and $\alpha ; \mathrm{N}_{1}=\mathrm{N}_{\mathrm{f}}+0.67 \mathrm{~N}_{\mathrm{m} 30}+0.33 \mathrm{~N}_{\mathrm{m} 60}$; see Table 3 for meaning of other symbols.

Table 7. Response curves of potatoes. Estimated values of the regression coefficients of Model 6 in Table 6. Standard errors are given in parentheses.

\begin{tabular}{lllll}
\hline $\begin{array}{l}\text { Soil } \\
\text { type }\end{array}$ & $\begin{array}{l}\text { Organic } \\
\text { manures }\end{array}$ & $\begin{array}{l}\mathrm{b}_{0} \\
\left(\mathrm{t} \mathrm{ha}^{-1}\right)\end{array}$ & $\begin{array}{l}\mathrm{b}_{1} \\
\left(\mathrm{t} \mathrm{ha}^{-1}\right)\end{array}$ & $\begin{array}{l}\mathrm{a} \\
\left(\mathrm{ha} \mathrm{kg}^{-1}\right)\end{array}$ \\
Sand & no & $59.0(0.76)$ & $-19.7(1.09)$ & $-0.0086(0.0013)$ \\
& yes & $57.2(0.58)$ & $-13.2(0.97)$ & $-0.0084(0.0015)$ \\
\multirow{2}{*}{ Loam } & no & $57.7(0.32)$ & $-18.9(0.67)$ & $-0.0119(0.0010)$ \\
& yes & $56.6(0.25)$ & $-17.3(0.79)$ & $-0.0149(0.0015)$ \\
Clay & no & $57.0(0.90)$ & $-14.7(1.78)$ & $-0.0115(0.0036)$ \\
& yes & $56.2(0.52)$ & $-13.4(1.59)$ & $-0.0117(0.0027)$ \\
\hline
\end{tabular}

effect of soil mineral nitrogen in the $0-30 \mathrm{~cm}$ layer was twice as large as that of the nitrogen in the 30-60 cm layer. In Models 4, 5 and 6 the amount of available nitrogen was assumed to equal $\mathrm{N}_{\mathrm{t}}$. Compared with Model 4 a significantly better fit of the nitrogen response was obtained in Model 5, where a distinction is made between fields which did and did not receive organic manures prior to the application of the inorganic fertilizer nitrogen (comparison of Model 5 with Model 4: $F=10.5$, $P<0.001$ ). The best fit was obtained in Model 6, in which not only the application of organic manures is taken into account, but also the type of soil (comparison of Model 6 with Model 5: $F=3.1, P<0.001$ ). 
Table 8. Economically optimum nitrogen requirement (fertilizer + soil mineral nitrogen according to Equation 7) of potatoes as affected by soil type and application of organic manures. The $90 \%$ confidence interval for the optima is given in parentheses.

\begin{tabular}{lll}
\hline Soil type & $\begin{array}{l}\text { Organic } \\
\text { manures }\end{array}$ & $\begin{array}{l}\text { Optimum nitrogen requirement } \\
\left(\mathrm{kg} \mathrm{ha}^{-1}\right)\end{array}$ \\
Sand & no & $410(356-486)$ \\
& yes & $370(280-467)$ \\
Loam & no & $320(294-351)$ \\
& yes & $265(236-307)$ \\
Clay & no & $306(254-388)$ \\
& yes & $295(265-353)$ \\
\hline
\end{tabular}

Table 9. Average values of measured maximum tuber yield and amount of nitrogen in the tubers of potatoes. The standard error is given in parentheses; $n=$ number of trials.

\begin{tabular}{llllll}
\hline $\begin{array}{l}\text { Soil } \\
\text { type }\end{array}$ & $\begin{array}{l}\text { Organic } \\
\text { manures }\end{array}$ & $n$ & $\begin{array}{l}\text { Maximum tuber } \\
\text { yield } \\
\left(\mathrm{t} \mathrm{ha}^{-1}\right)\end{array}$ & $\begin{array}{l}\mathrm{N} \text { in tubers } \\
\text { at maximum } \\
\text { tuber yield } \\
\left(\mathrm{kg} \mathrm{ha}^{-1}\right)\end{array}$ & $\begin{array}{l}\mathrm{N} \text { in } \\
\text { tubers } \\
\left(\mathrm{kg} \mathrm{t}^{-1}\right)\end{array}$ \\
Sand & no & 14 & $61.4(1.34)$ & $244(5.59)$ & 3.97 \\
& yes & 11 & $60.9(2.60)$ & $231(9.28)$ & 3.79 \\
Loam & no & 28 & $53.1(1.59)$ & $199^{*}(7.41)$ & 3.75 \\
& yes & 27 & $57.3(1.69)$ & $214(7.08)$ & 3.73 \\
Clay & no & 6 & $58.4(4.09)$ & $226(16.41)$ & 3.87 \\
& yes & 12 & $59.4(2.74)$ & $231(11.68)$ & 3.89 \\
\hline
\end{tabular}

${ }^{*} n=26$.

The estimated values of the regression coefficients of Model 6 are given in Table 7. The economically optimum nitrogen requirement for the various soil types with and without application of organic manures was then calculated (Table 8). In the optima of Table 8, fertilizer nitrogen and soil mineral nitrogen are both included according to Equation 7. The ratio of the cost of $1 \mathrm{~kg}$ nitrogen (fertilizer + soil mineral nitrogen according to Equation 7) to the price of 1 tonne potato tubers, $P$ in Equation 5 , was assumed to be 0.005 . Without organic manures the optimum nitrogen requirement (fertilizer and soil mineral nitrogen) on sandy soils was about $100 \mathrm{~kg} \mathrm{~N}$ per ha higher than on loam and clay soils. When organic manures were applied prior to the application of fertilizer nitrogen, the optimum was $15-50 \mathrm{~kg} \mathrm{~N}$ per ha lower than that obtained without application of organic manures.

To help explain the differences in response to nitrogen, the measured maximum tuber yields and the corresponding amounts of nitrogen in the tubers are given in Table 9. The highest yields and nitrogen uptakes were generally obtained on the sandy soils. 


\section{Discussion}

\section{Soil mineral nitrogen}

The results presented show that response of sugar beet and potatoes to nitrogen is not only dependent on the rate of fertilizer nitrogen application but also on the amount of soil mineral nitrogen present in early spring before fertilizer is applied. This finding is not new, and has been reported extensively in the literature (Greenwood, 1986). However, no differentiation has been made so far between the contribution of mineral nitrogen in the various soil layers to the nitrogen response. When more than one layer was taken into account, the contributions of soil mineral nitrogen in the different layers were given equal weight (Boon \& Vanstallen, 1983; Lindén, 1987; Maidl \& Fischbeck, 1986; Müller \& Moritz, 1982; Stieberitz et al., 1986).

The results presented in this paper demonstrated that, for sugar beet, the contribution of soil mineral nitrogen in the $0-30 \mathrm{~cm}$ layer was about the same as that in the $30-60 \mathrm{~cm}$ layer and that it was about $80 \%$ of the contribution of fertilizer nitrogen. The contribution of soil mineral nitrogen in the 60-100 cm layer, however, was 5-6 times smaller and was assumed to be negligible. For potatoes the contribution of soil mineral nitrogen in the $0-30 \mathrm{~cm}$ layer to the response to nitrogen was $67 \%$ of that of fertilizer nitrogen, and it was $33 \%$ for the 30-60 cm layer. The relatively larger contribution of fertilizer nitrogen in the case of potatoes compared with sugar beet is probably the result of the fact that potatoes are grown in ridges. When the ridges are made and the tubers are planted, the fertilizer, which is usually broadcast shortly before, is moved close to the tubers. The results further suggest that uptake of nitrogen by sugar beet and potatoes predominantly takes place in the 0-60 and 0$30 \mathrm{~cm}$ layer, respectively. It was reasoned that the differences between the two crops in uptake from these layers could be attributable to differences in root density. However, in the literature no large differences in root density between sugar beet and potatoes in the $0-30$ and $30-60 \mathrm{~cm}$ layer could be found, but root density in the $60-90 \mathrm{~cm}$ layer was found to be higher for sugar beet than for potatoes (de Willigen \& van Noordwijk, 1987). Downward movement of nitrate can occur in spring, and the nitrate originally present in the $30-60 \mathrm{~cm}$ layer is then partly leached into the $60-90 \mathrm{~cm}$ layer, where it is still available to sugar beet, but not to potatoes.

For potatoes, another reason for the relatively low contribution of the amount of soil mineral nitrogen in the $30-60 \mathrm{~cm}$ layer in Equation 7 is the high correlation between the amount of mineral nitrogen present in the $0-30 \mathrm{~cm}$ layer and that in the $30-60 \mathrm{~cm}$ layer $\left(r^{2}=0.83\right)$.

\section{Soil type}

The response of potatoes to fertilizer nitrogen and soil mineral nitrogen was much higher on sandy soils than on clay and loam soils. Lauer (1986) and Müller et al. (1986) also found a stronger response of potatoes on sandy soils and attributed it to a higher susceptibility to nitrate leaching and/or a lower nitrogen mineralization 
rate. Heavier nitrogen losses in sandy soils through leaching in the interval between early spring and the end of the uptake period of nitrogen by the potatoes played probably a role. It is unlikely, however, that the rate of mineralization was lower in sandy soils, because in the present experiments uptake of nitrogen by the crop on plots without fertilizer nitrogen (0N plots) varied little among the soil types: calculated on the basis of the measured values of the amount of nitrogen present in the tubers and the assumption that total nitrogen uptake is 1.2 times the amount of nitrogen present in the tubers (Neeteson et al., 1987), crop uptake on the $0 \mathrm{~N}$ plots of fields without organic manures was, on average, $139 \mathrm{~kg} \mathrm{ha}^{-1}$ on the sandy soils, 120 $\mathrm{kg} \mathrm{ha}^{-1}$ on the loam soils, and $144 \mathrm{~kg} \mathrm{ha}^{-1}$ on the clay soils.

Another reason for the stronger response of potatoes on sands could be the higher yield level obtained (Table 9). The amount of nitrogen in the tubers per unit of yield was largely independent of the maximum yield level (Table 9), and as the amount of nitrogen in the tubers is linearly related to total uptake of nitrogen (Neeteson et al., 1987), higher yields are accompanied by higher nitrogen requirements.

The response of sugar beet to fertilizer nitrogen and soil mineral nitrogen was also higher on sandy soils, although to a much lesser extent than in the case of potatoes. Draycott \& Durrant (1973) and Webster et al. (1977) also found that sugar beet required more nitrogen on sandy soils than on heavier soils. Nitrogen losses as a result of the higher risk of leaching are probably responsible for the somewhat stronger response on sands. Because there are no data available on nitrogen uptake by sugar beet in the experiments described in this paper, it cannot be checked whether nitrogen mineralization rates on the sugar-beet fields were different for the different soil types. Again, it is unlikely that the soils differed in mineralization rate, because generally the same fields were used for sugar beet as well as potato production. It is unlikely either that the yield level obtained by the sugar beet on sands played a role. On the contrary, without application of organic manures the maximum yields on the heavier soils tended to be higher. They were $58.2 \pm 2.69$, $64.5 \pm 1.24$ and $62.3 \pm 2.56 \mathrm{tha}^{-1}$, on sandy, loam, and clay soils, respectively.

\section{Organic manures}

When organic manures were applied prior to the application of fertilizer nitrogen, the response of both sugar beet and potatoes to fertilizer nitrogen and soil mineral nitrogen was weaker than when no organic manures were applied. To get an estimate of the amount of nitrogen mineralized from the organic manures, the average total uptake, i.e. 1.2 times the measured amount of nitrogen in the tubers (Neeteson et al., 1987), on $0 \mathrm{~N}$ plots on fields without organic manures was subtracted from the uptake on fields with organic manures. The extra uptake on fields with organic manures averaged $30 \mathrm{~kg} \mathrm{ha}^{-1}$ on sandy soils, $43 \mathrm{~kg} \mathrm{ha}^{-1}$ on loam soils, and $49 \mathrm{~kg} \mathrm{ha}^{-1}$ on clay soils. These figures are in agreement with the amount expected when $50 \mathrm{t}$ cattle slurry per ha is applied in autumn containing $0.44 \% \mathrm{~N}$ and having an efficiency index of $20 \%$ (Kolenbrander, 1981), or when ryegrass or a legume is grown as a green manure (Last et al., 1981). The extra uptake of $30-50 \mathrm{~kg} \mathrm{~N}$ per ha is partly the result of nitrogen which was mineralized from the organic manures during au- 
tumn and winter and which was included in the measurement of soil mineral nitrogen in early spring, and partly from the amount of nitrogen mineralized afterwards. When organic manures had been applied, the amount of soil mineral nitrogen in the $0-60 \mathrm{~cm}$ layer in early spring was on sandy soils on average 24 , on loam soils 25 , and on clay soils $52 \mathrm{~kg} \mathrm{~N}$ per ha larger than when no organic manures had been applied. When it is assumed that the recovery by the crop of soil mineral nitrogen in early spring was $50 \%$ and that the nitrogen mineralized in the growing season is entirely taken up by the crop, the amount of nitrogen mineralized from the organic manures in the growing season was on average 18,31 , and $23 \mathrm{~kg} \mathrm{~N}$ per ha, on sandy, loam, and clay soils, respectively.

Apparently, a substantial part of the nitrogen from organic manures is mineralized in the growing season, but is not explicitly accounted for in the current nitrogen fertilizer recommendations in the Netherlands (Anon., 1986). It therefore appears to be better to take the extra amount of nitrogen mineralized from organic manures during the growing season into account in the nitrogen fertilizer recommendations, as is currently practised in the Federal Republic of Germany (Wehrmann \& Scharpf, 1986).

\section{Nitrogen fertilizer recommendations}

On the basis of the results presented in Tables 5 and 8 , general guidelines for the economically optimum application rate of fertilizer nitrogen for sugar beet and potatoes can be drawn up. It remains to be investigated whether these refined recommendations, which not only take soil mineral nitrogen into account, but also soil type and prior application of organic manures, are more effective than the current recommendations.

\section{Acknowledgement}

Thanks are due to the Sugar Beet Research Institute (IRS, Bergen op Zoom) for supplying data on sugar-beet trials.

\section{References}

Anon., 1986. Fertilizer recommendations for arable crops (in Dutch). Consulentschap voor bodem-, water-en bemestingszaken in de akkerbouw en tuinbouw, Wageningen, $28 \mathrm{pp}$.

Boon, R. \& R. Vanstallen, 1983. Avis de fumure azotée pour betteraves sucrières sur base de l'analyse de terre. In: Proceedings Symposium 'Nitrogen and Sugar Beet', p. 433-445. International Institute for Sugar Beet Research, Brussels.

Draycott, A. P. \& M. J. Durrant, 1973. The influence of previous cropping and soil texture on the nitrogen requirement of sugar beet. Experimental Husbandry 25: 41-51.

Greenwood, D. J., 1986. Prediction of nitrogen fertilizer needs of arable crops. Advances in Plant Nutrition 2: 1-61.

Kolenbrander, G. J., 1981. Limits to the spreading of animal excrement on agricultural land. In: J. C. Brogan (Ed.), Nitrogen losses and surface run-off, p. 443-468. ECSC/EEC/EAEC, Brussels.

Last, P. J., A. P. Draycott \& D. J. Webb, 1981. Effect of green manures on yield and nitrogen requirement of sugar beet. Journal of Agricultural Science (Cambridge) 97: 159-170. 
Lauer, D. A., 1986. Response of Nooksack potatoes to nitrogen fertilizer. American Potato Journal 63: 251-262.

Lindén, B., 1987. Reasons for variations in optimum demand of fertilizer nitrogen in sugar beet production. In: N. E. Nielsen (Ed.), Proceedings 3rd Meeting NW European study group for the assessment of nitrogen fertilizer requirement, p. 72-87. The Royal Veterinary and Agricultural University, Copenhagen.

Maidl, F. X. \& G. Fischbeck, 1986. Veränderungen des bodenbürtigen Mineralstickstoffs im Frühjahr und seine Bedeutung für die Bemessung der N-Düngung von Zuckerrüben. Journal of Agronomy and Crop Science 156: 1-12.

Müller, S., H. Görlitz, K. Benthin, W. Neubauer, W. Mirswa, J. Stieberitz \& R. Kopp, 1986. Bedarfsgerichte Stickstoffdüngung der Kartoffeln unter besonderer Berücksichtigung des anorganischen Bodenstickstoffs. Archiv für Acker- und Pflanzenbau und Bodenkunde 30: 631-637.

Müller, S. \& D. Moritz, 1982. Untersuchungen zur N-Düngung von Zuckerrüben unter besonderer Berücksichtigung des Gehaltes an anorganischem Stickstoff im Boden. Archiv für Acker- und Pflanzenbau und Bodenkunde 26: 39-45.

Neeteson, J. J., 1982. Investigation into the relationship between amount of soil mineral nitrogen and optimum nitrogen fertilization for potatoes and sugar beet. In: L. M. J. Verstraeten \& T. Batey (Eds), Assessment of the nitrogen status of soils, p. 44-47. Catholic University of Leuven.

Neeteson, J. J., D. J. Greenwood \& A. Draycott, 1987. A dynamic model to predict yield and optimum nitrogen fertiliser application rate for potatoes. Proceedings 262 . The Fertiliser Society, London, 31 pp.

Neeteson, J. J. \& W. P. Wadman, 1987. Assessment of economically optimum application rates of fertilizer $\mathrm{N}$ on the basis of response curves. Fertilizer Research 12:37.52.

Ris, J., K. W. Smilde \& G. Wijnen, 1981. Nitrogen fertilizer recommendations for arable crops as based on soil analysis. Fertilizer Research 2: 21-32.

Steur, G. G. L. \& W. Heijink, 1987. General conceptions and classifications. Soil map of the Netherlands (3rd ed.) (in Dutch). Stichting voor Bodemkartering, Wageningen, 64 pp.

Stieberitz, J., R. Kopp \& M. Langermann, 1986. Untersuchungen zur Berücksichtigung des anorganischen Bodenstickstoffs bei der Bemessung der Stickstoffdüngung im Kartoffelbau. Archiv. für Ackerund Pflanzenbau und Bodenkunde 30: 623-630.

Webster, R., C. A. H. Hodge, A. P. Draycott \& M. J. Durrant, 1977. The effect of soil type and related factors on sugar beet yield. Journal of Agricultural Science (Cambridge) 88: 455-469.

Wehrmann, J. \& H. C. Scharpf, 1986. The Nmin-method - an aid to integrating various objectives of nitrogen fertilization. Zeitschrift für Pflanzenernährung und Bodenkunde 149: 428-440.

Willigen, P. de \& M. van Noordwijk, 1987. Roots, plant production and nutrient use efficiency. Doctoral thesis, Agricultural University Wageningen, $282 \mathrm{pp}$. 